\title{
UNA NARRATIVA QUE NO AMA A LAS MORAS: ANÁLISIS COMPARADO DE LA VIOLENCIA DE Y HACIA LA MUJER MARROQUÍ EN TEXTOS LITERARIOS ESPAÑOLES
}

\author{
Yasmina Romero Morales \\ Universidad de La Laguna \\ yasminaromero@hotmail.com
}

\begin{abstract}
RESUMEN: El presente artículo tiene como objetivo analizar la violencia que ejerce la mujer marroquí imaginada en la narrativa española de ficción escrita por mujeres durante el siglo XX pero, también, la violencia a la que es sometida. La literatura, al igual que otros soportes culturales, contribuye en el proceso de construcción, consolidación y transmisión de imaginarios de «otras» culturas que ayudan a la naturalización de estereotipos y prejuicios que se defienden como verdades incuestionables. En este caso, el orientalismo ha logrado que en el orden simbólico occidental sobre lo marroqui predomine su caracterización como violento. La narrativa española de tema marroqui refuerza esta idea hasta tal punto que con la excusa de "reflejar" la realidad de un país árabe-islámico, lo que consigue, performativamente, es instaurar esa realidad social en el imaginario generalizado.

PALABRAS CLAVE: literatura española, literatura comparada, orientalismo, violencia, Marruecos, mujeres escritoras.
\end{abstract}

\section{A NARRATIVE THAT DOES NOT LOVE MOOR WOMAN: A COMPARATIVE ANALYSIS OF VIOLENCE OF AND TOWARD MOROCCAN WOMAN IN SPANISH LITERARY TEXTS}

\begin{abstract}
This article aims to analyze the violence of the Moroccan woman imagined in the Spanish fiction narrative written by women during the 20th century, but also the violence to which she is subjected. Literature, like other cultural media, contributes in the process of constructing, consolidating and transmitting imaginaries of "other" cultures that help the naturalization of stereotypes and prejudices that are defended as unquestionable truths. In this case, Orientalism has achieved that the Western symbolic order on the Moroccan predominates its characterization as violent. The Spanish narrative of Moroccan topic strengthens this idea to such an extent that with the excuse of "reflecting" the reality of an Arab-Islamic country, what is achieved, performatively, is to establish that social reality in the generalized imaginary.

KEYWORDS: Spanish literature, Comparative Literature, Orientalism, violence, Morocco, women writers.
\end{abstract}

Recibido: 15/10/2017. Aceptado: 27/02/2018 


\section{Introducción}

La literatura, al igual que otros soportes culturales, contribuye al proceso de construcción, consolidación y transmisión de imaginarios de "otras" culturas que ayudan a la naturalización de estereotipos y prejuicios que se defienden como verdades incuestionables. El orientalismo ha logrado que en el orden simbólico occidental sobre lo marroquí predomine su caracterización como violento. Estudiosas como Lily Litvak señalan que el único orientalismo que suscita Marruecos es violento, sin embargo, debe admitirse que el mundo árabe-islámico en su conjunto constituye, también en opinión de Litvak, una "metáfora de la crueldad" (1985: 113)1. La narrativa española de tema marroquí refuerza esta idea hasta tal punto que con la excusa de "reflejar" la realidad de un país árabe-islámico, en verdad lo que consigue, performativamente, es instaurar esa realidad social aunque sólo sea en el imaginario generalizado.

De entre las cientos de obras de la literatura española que tienen a Marruecos como tema central (López García 1994; Carrasco González 2000; López Barranco 2006), el presente estudio se centra sólo en aquellas escritas por mujeres y durante el siglo $\mathrm{XX}^{2}$. En lo tocante a la elección del siglo XX vino motivada, además de por su contemporaneidad, porque son los años de mayor relación histórica y política entre Marruecos y España. Pocas familias españolas no tienen un padre o un abuelo que haya participado en cualquiera de las muchas guerras con Marruecos y haya legado de esa manera imágenes emocionales del norte de África. Durante la primera mitad del siglo XX, exactamente hasta 1956, año de la independencia de Marruecos, es cuando más producción española de tema marroquí se publica, era lo que por aquellos tiempos se conocía como "la cuestión de Marruecos", por su repercusión en la política y en la vida de la nación. A partir de entonces, empieza a decaer paulatinamente el interés y, en la actualidad, sólo una o dos novelas al año de esta temática consiguen llegar al mercado editorial español. Con todo y con eso, estamos ante un conjunto literario con "entidad y dimensión propias" (Martínez Montávez 1976-7: 22) que, por supuesto, no nos dirá cómo

1. Para ahondar en la imagen violenta con la que suele ser descrito el mundo árabe-islámico, véase el capítulo de LITVAK, L. (1985). "Crueldad y violencia" en El Jardín de Aláh. Temas del exotismo musulmán en España 1880-1913, 84-120.

2. Las autoras usadas en este estudio son veintidós: Carmen Martel, Concha López Sarasúa, Encarna Cabello, Marisa Villardefrancos, Regina Flavio, Concha Linares-Becerra, Mari Paz Estévez de Castro, Cristina Fernández Cubas, Carmen de Burgos, María Charles, Carmen Martín de la Escalera, María Teresa de Jadraque, María Viñuelas, Blanca Ibáñez Blanco, Josefina María Rivas, Rosa de Aramburu, María Adela Durango, Margarita Astray Reguera, Rosa María Aranda, Julia María Abellanosa, Carmen Nonell y Dora Bacaicoa. 
era realmente la sociedad marroquí -no son estas páginas ningún subterfugio para llevar a cabo observaciones de tipo sociológico sobre las condiciones reales de las mujeres que habitan al otro lado del Estrecho, de hecho muchas de las escritoras ni siquiera habían pisado jamás el país vecino- pero sí nos aproximará a otra realidad, a aquella que nos habla de los estereotipos compartidos por las autoras que la narran, en tanto en cuanto aportan valiosa información de contenido ideológico sobre cómo la percibían, la imaginaban y la pensaban.

Respecto a la elección única de mujeres escritoras, se debe a que la institución literaria se organiza de forma sexista -también clasista, claro está, pero me interesa sobre todo subrayar los efectos demoledores de las adscripciones por motivo de género- y me interesa visibilizar a las autoras de los textos de los que me he servido como análisis como una forma de contribuir a su incorporación al canon hegemónico masculino que las ha ignorado de manera sistemática. $\mathrm{Y}$ es que, como opina Toril Moi, "en una sociedad machista que discrimina a las escritoras precisamente porque son mujeres es fácil justificar el estudiarlas como grupo aparte" (1988: 91). En otro orden de cosas, atender a estas mujeres escritoras como sujetos de estudio ambicionaba, también, observar no sólo su capacidad de engendrar otredad sino la naturaleza de esa otredad generada, esto es, comprobar si esos "otros" y "otras" imaginados para sus ficciones, recibían un retrato menos fustigador, menos acusador, que el retrato creado por los escritores hombres para su narrativa de la misma temática. Principalmente, porque ellas hayan podido comparar la situación de sumisión y discriminación por motivo de género que padecían en su país de origen, con la subordinación por etnia-raza del país que imaginaban. En otras palabras, comprobar si quizá eran menos racistas o más críticas con el trato diferente y perjudicial que se le daba a esta "otredad" por motivos de raza, etnia o religión por el hecho mismo de hallarse identificadas en el abuso.

Finalmente, el interés perseguido en estas páginas es analizar, desde la perspectiva de género y las teorías postcoloniales, la violencia a la que es sometida la "otra" marroquí imaginada en estos textos españoles, novelas y cuentos que han contribuido a reforzar la imagen mental occidental de la "otredad" de origen árabe-islámico como violenta, sin hacer en casi ningún caso objeciones a esta construcción cultural, sino reforzando la naturalización del axioma occidental. De algún modo, este trabajo quiere ayudar a proveer de herramientas críticas de resistencia al público lector ante un modo de representación que, a pesar de que insiste en su universalidad, es cómplice de los esquemas del etnocentrismo y del androcentrismo, en la medida que la narrativa analizada está elaborada desde un 
contexto patriarcal y europeo en el que la persona que lee absorbe los procesos de ideologización difundidos en la misma. La perspectiva de género no es sólo una teoría de análisis es, también, una praxis, por lo que aspira a la aniquilación del patriarcado y, para ello, necesita que el público lector sea resistente ante los procesos ideológicos presentes en los textos literarios.

\section{La violencia como tópico literario en la narrativa española de tema marroquí}

El álbum de fotografías de la historia compartida entre España y Marruecos ha sido una ida y venida de instantáneas de enfrentamientos que tuvieron no sólo coste económico sino también miles de vidas humanas de ambos bandos. Es más, si a cualquier investigador o investigadora que haya estudiado la relación histórica de España con Marruecos le pidieran que hiciera una síntesis reciente, probablemente optaría por hacer una enumeración de los enfrentamientos de los que, además, existe una extensa bibliografía. Un conocimiento exhaustivo de esta historia compartida hispano-marroquí, en opinión de muchos, contribuiría a entender mejor la narrativa española de tema marroquí analizada -fuentes primarias de este trabajo- porque como es evidente estos conflictos y contactos sirvieron de telón de fondo a gran parte de las contribuciones literarias que someto a estudio. Y es que durante la primera mitad de la pasada centuria, un vistazo rápido en la hemeroteca a la prensa de la época, nos devuelve noticias diarias sobre los avances, y también retrocesos, del ejército español en el frente. Fue de este modo como la cuestión marroquí se convirtió en una de las materias políticas nacionales de mayor trascendencia. Incluso después de acabada la ocupación colonial en el norte de África, se sigue sacando a colación la importante basa que jugó Marruecos en acontecimientos tan decisivos para la historia oficial contemporánea española, como el descontento que favoreció la llegada de la Segunda República (1931-1939) o el origen de la Guerra Civil de 1936.

Sin embargo, como se ha señalado con anterioridad, uno de los sostenes teóricos de este trabajo son las teorías postcoloniales $\mathrm{y}$, éstas a su vez, no pueden desligarse del giro posmoderno que cuestiona el tipo de historia que nos ha sido legada: "Whose history gets told? In whose name? For what purpose? Postmodernism is about histories not told, retold, untold. History as it never was. Histories forgotten, hidden, invisible, considered unimportant, changed, eradicated" (Marshall 1992: 4).

Este es el motivo por el que estas páginas no se detienen en demasía en la historia oficial heredada, dado que ésta ha sido transmitida desde patrones 
tradicionales y lineales y forma, en sí misma, un ámbito de estudio marcado transversalmente por discursos y posiciones - marginales o céntricas- en conflicto con el poder. Sin embargo, lo que sí es cierto, es que "la creación no sucede en una campana de vidrio" (Atwood 2013: 38) por lo que estas guerras y conflictos hispano-marroquíes han sido generadoras y reforzadoras, en buena medida, del sistema de representación que ha configurado a la otredad marroquí durante el siglo XX y que se reduce a una vertiente principalmente política del orientalismo clásico. Dicho de otro modo, el orientalismo político que subyace en las páginas analizadas alude a un discurso reduccionista e uniforme del mundo árabe y del islam, caracterizado por polarizaciones entre lo bueno y los buenos, y lo malo y los malos, con generalizaciones excesivas y sin atender a ningún tipo de avance cultural, político o social.

A todo ello ayudaron los muchos conflictos bélicos entre España y Marruecos y que iban, invariablemente, unidos a la idea de muerte y luto. De ahí que la otredad marroquí, desde el discurso orientalista, sea considerada un colectivo sin matices ni particularidades individuales y que todos los marroquíes sean violentos e igual de violentos. Las ficciones devuelven múltiples ejemplos en esta línea; se dice que son violentos y lo son porque son musulmanes, se les despoja de subjetividad individual y se subraya su homogeneidad: en Marruecos "la ley del talión sigue en todo vigor" (Villardefrancos 1953: 25); los rifeños son "de ferocidad indomable" (Burgos 1989: 175); "una legión de traidores" (Aranda 1945: 99); el moro migrante sólo trae problemas a la Península y, por ello, se dice que "[1] a sombra de la cárcel pululaba sobre sus cabezas" (Cabello 1995: 43); los niños "llevan en la sangre el hábito guerrero" (Charles 1993: 109); son malos "por el gusto de serlo" (Villardefrancos 1953: 31) y no se reprimen a la hora de proferir agravios y ofensas: "como buen moro, no se resignó sin una lluvia de insultos denigrantes aplicados al doctor y a sus criados" (Villardefrancos 1953: 12). La idea dominante fue que el moro era "maestro en crueldades" (Astray Reguera 1925: 11) porque "Mahoma regaló muchas pasiones, pero ésta, la del rencor, está en la sangre y en el meollo de la raza" (Villardefrancos 1953: 26)3.

3. Sólo algunas autoras, como Aranda, Charles o Cabello combaten el estereotipo de la violencia en sus textos y apuestan por realidades plurales. Unas veces menguando el tópico: "Son vengativos, mas si usted les hace algún favor o les trata simplemente con miramiento, no lo olvidarán jamás" (Aranda 1945: 99). Otras veces haciendo que algunos de sus personajes den prueba con su testimonio de la falsa acusación que supone decir que la violencia es algo consustancial al pueblo marroquí: "jamás ninguno de su raza ha querido hacerme daño" (Aranda 1945: 100). En otros casos desestabilizando el tópico, haciendo a los personajes españoles ejercer la misma violencia: “iMoros de mierda! ¡Idos a casa!” (Cabello 1995: 21). Más demostrativo es el médico de Tebib (1945) que llega a admitir que es brusco, impulsivo y que, en ocasiones, debe arrepentirse "de cosas que hace en uno de sus momentos salvajes" 
Los personajes femeninos marroquíes participan de dicha estereotipia y, por tanto, también se recogen múltiples ejemplos de su caracterización violenta. Los grados de los actos violentos oscilan desde lo más inofensivo, como la mora que gusta de tirar cáscaras de limón desde su azotea a los españoles "el juego ingenuo le llenaba de contento" (Aramburu 1937: 81), las peleas entre mujeres como Jaddux y Rajma en Noche nupcial sin novia (1956) o, incluso, las que dedicadas a actos delictivos, secuestran y maltratan "a cuanto vejamen pueda soportar una persona humana" (Rivas 1949: 143).

Pero aún hay un grado mayor de violencia ejercida por las moras de estas ficciones. Lo vemos en Ojos largos (1937) donde incluso llegan a matar. En esta historia tres esposas sienten celos y envidia ante la recién llegada cuarta mujer, Nefisa, una muchacha bella y joven. En un principio manifiestan sus rivalidades y pasiones rompiendo sus caftanes e insultándola de la "forma más ostensible" (Aramburu 1937: 151). Sin embargo, no les fue suficiente y la parte final de la trama gira en torno a los diversos intentos de asesinato de la joven a la que no sólo desean la muerte, sino que perezca con dolor. Así, se relata como una vendedora de ungüentos les asegura que con su remedio Nefisa no sólo morirá sino que se “desgarrará el rostro, dará unos gritos terribles" (Aramburu 1937: 150). Justo eso es lo que quieren, pero les costará varios intentos: casi consiguen matarla dejando caer sobre ella un candelabro pesado, también le introdujeron vidrio molido en el interior del cuzcuz para intentar de esta manera que el cristal perforara sus intestinos y, al fin, le dan muerte con veneno.

Aflora en este caso uno de los muchos ejemplos que esta narrativa ofrece de violencia entre mujeres. La dependencia económica y social respecto a los hombres es la que la genera principalmente, sobre todo porque en muchas de las ficciones, y en virtud del tópico de la poligamia islámica, son varias las esposas de un mismo hombre, porque ya sabemos, "ellos no se conforman con una sola" (López Sarasúa 2000: 212), lo más normal es que todos estén casados “y quizá con más de una mujer..." (Flavio 1938?: 57), porque se les permite "que tengan hasta cuatro esposas" (Aramburu 1937: 97), así que cuando mueren pueden dejar más de una viuda (López Sarasúa 2000: 236).

A veces esta poligamia se explica por razones que desde Occidente parecen inadmisibles, como considerar a tu primera esposa de veintisiete años vieja $y$,

(Aranda 1945: 59). Por último, pero en esta misma línea, cabe mencionar el asesinato en Etxezarra (1993) de un jovencísimo marroquí por parte de las milicias españolas. Los soldados españoles le hunden en el pecho la bayoneta con ferocidad, aún reconociendo que es imberbe (Charles 1993: 65). 
por ello, contraer segundas nupcias con una de dieciséis. Sucede esto en Alma de Marruecos (1938?). Con todo, y en general, esta rivalidad y competencia femenina no difiere de la que Occidente ha inculcado en sus mujeres.

Hay muchos ejemplos más de moras que son violentas con otras mujeres, sean o no son moras, y que disfrutan ejerciendo la violencia, como Arbuissa de Noche nupcial sin novia (1956) que siente un odio desmesurado por la mora Redia. Le profiere todo tipo de maldades -desde escupirle a los pies hasta engañarla para que contraiga matrimonio con un anciano- y luego la busca para preguntarle con sarcasmo: “¿Sufres?” (Ibáñez Blanco 1956: 104). O, también, las ancianas de las que se asegura que son "seres perversos que, poco a poco, han ido llenando sus cuerpos de veneno" y gustan de ir a contarles a los maridos de las jóvenes que han roto las normas, por el placer de saber que "aquellos las vapuleen" (Aramburu 1937: 31).

La violencia de la "otra" marroquí está también presente en el campo de batalla, algo que llama mucho la atención en la medida que el imaginario de lo militar en la cultura occidental ha sido siempre eminentemente masculino. Incluso en la literatura, donde más allá de la Bradamante de Ariosto, la Clorinda de Tasso o la propia Juana de Arco o Catalina de Erauso no suele recoger representaciones femeninas de mujeres soldado. Pero esta narrativa de tema marroquí, no olvidemos, tiene como una de sus características principales que convivió durante más de la mitad del siglo XX con conflictos bélicos hispano-marroquíes, de ahí que la descripción de la violencia sea determinante incluso en este caso femenino. Dice Narlina, la supuesta esclava árabe de la novela Halima (1954), "Yo he estado en todas partes, sidi. Mi raza ha poseído medio mundo y luchado en otro medio" (Jadraque 1954: 63).

Para ser justos, no siempre la violencia atribuida a la otredad marroquí fue falsa, no todos los estereotipos lo son completamente, pero sí es verdad que en esta narrativa se obvian los excesos de un bando y se refuerzan hasta la saciedad los del otro para conseguir demonizarlos. Algo que, además, no suena a nuevo en la Península Ibérica, acostumbrada a las luchas seculares de la cristiandad española contra el islam peninsular que habían ido consolidando fuertes prejuicios en contra de los musulmanes.

A causa de lo anterior, tras el análisis de estos relatos, se advierte que se acentúan las acciones de la mora en el campo de batalla no como propias de la guerra en la que se encuentran ambos bandos enzarzados, sino como crímenes derivados de la supuesta naturaleza sanguinaria que le es propia y es que, "las 
mujeres moras somos un poco salvajes" (Durango 1943: 29). Esta sed de sangre, que refuerza especialmente el sentimiento anti-islámico, aparece desde la primera novela analizada: En la guerra (1909) de Carmen de Burgos. En este texto se presenta a las mujeres marroquíes como violentas y parte activa de las contiendas que se estaban llevando a cabo en el norte de África:

Ellas eran las que les llevaban armas, municiones, víveres, les alentaban ferozmente a la matanza y hasta les ayudaban saciando su odio religioso, con ese apasionamiento de la mujer contra los rumí, malditos por sus santones. Apaleaban con porras de madera, claveteadas de hierro, a los soldados rendidos y moribundos. Más de una mora había perecido en el campo de batalla y algunas se arañaban el rostro con desesperación de furias infernales cuando sufrían una derrota. No iban a la lucha por amor a los suyos, sino por ferocidad, por odio al enemigo. (Burgos 1989: 210)

Es de esta manera como la "otra" marroquí de las fuentes analizadas se introduce en un mundo codificado en masculino. Sin embargo, la incorporación de la mujer marroquí al escenario de la guerra no debe valorarse como una muestra de empoderamiento femenino frente a las españolas a las que, durante gran parte del siglo pasado, debido a la repartición de roles por cuestión de género, no se las dejó ejercer de militares. En primero lugar, porque las marroquíes de esta narrativa no participaban en la guerra desde dentro de la estructura militar, sino como actos espontáneos y esporádicos y, en segundo lugar, porque esta representación bélica no era sino una forma más de subrayar su salvajismo frente a los deseos de paz propios de las españolas. Leamos, por poner un ejemplo, lo que dice de sí misma la española Alina en la novela de Carmen de Burgos: "Me asusta el derramamiento de sangre. El dolor de los que pierden seres queridos. Ya que no puedo evitar los males, quisiera prestar algún consuelo". (Burgos 1989: 170)

Adviértase que, a diferencia de las rifeñas a las que se describe como ávidas de combate y vengativas, las mujeres españolas son en esta narrativa su contrapunto. Para ellas el frente es cosa de hombres y su único protagonismo en época de guerra es llorar la pérdida de sus seres queridos. Las mujeres españolas no son combatientes, son viudas, huérfanas o madres afligidas de sus caídos en el frente. Por eso, Alina -una suerte de representante de la mujer española en Marruecos- sueña con un mundo en el "que ya no habría guerras" (Burgos 1989: 169), porque piensa "únicamente con el corazón” y "se da continuamente a todos los que sufren” (Burgos 1989: 170). 
Sin embargo, las mujeres marroquíes de esta narrativa no son sólo sujetos que ejercen violencia, sino que también, y principalmente, son objeto de la misma. Se pueden hallar tantos ejemplos de violencia hacia las mujeres autóctonas en las ficciones analizadas que podría inferirse que nos encontramos ante un corpus documental íntegramente misógino. Al menos, misógino hacia las mujeres marroquíes que no son sólo maltratadas por hombres marroquíes, sino también por hombres españoles ${ }^{4}$. Esto es especialmente revelador, en la medida que -aún sin quererlo las autoras, probablemente- pone en evidencia que el patriarcado es un andamiaje ideológico basado en la inferioridad natural de las mujeres respecto a los hombres y que da lugar a relaciones asimétricas y jerárquicas entre sexos que no entienden de culturas ni de etnias. Así, la misoginia que destilan los relatos y novelas analizados, y que podría tener, efectivamente, una correspondencia factual en el Marruecos del otro lado del Estrecho, no abunda - pese a la que pudiera ser la intención de las autoras-en el retrato negativo de la otredad árabe-islámica, en la medida que incluir, también, maltratadores españoles demuestra que no es privativo de su cultura. Y es que, qué duda cabe, la violencia de género, en sus diversas formas, se da en todos los escenarios del globo y cualquier mujer es susceptible de sufrirla, independientemente del lugar donde nazca.

En las páginas que siguen me detendré en las violencias hacia la "otra" que predominan en esta narrativa de tema marroquí. Las dimensiones principales a estudio serán la simbólica, la estructural, la física y la sexual, aunque de ningún modo hay afán de exhaustividad sino de establecer una fotografía de conjunto de los distintos escenarios de violencia femenina habituales en esta narrativa.

\subsection{Violencia simbólica}

La violencia simbólica, en el sentido que le da Bourdieu, imperceptible a la vista e invisible para sus propias víctimas es, sin embargo, notoria en el examen de las fuentes y atribuida en todos los casos al legado cultural de origen. La hallamos desde el mismo nacimiento de la "otra" marroquí donde, por ser niña, todos los familiares guardan silencio. Las autoras, conocedoras de la organización

4. Puede resultar interesante detenerse en la etimología de la palabra violencia en este momento. Violencia procede de la palabra latina violentus, de violare. La raíz de esta palabra proviene, asimismo, de vis que sabemos que significa 'fuerza' y que, no por casualidad, se vincula a la palabra vir que significa 'hombre' (de ahí todas las palabras de su familia léxico como virilidad o viril): "es de varones fuertes hacerse abominables" (Ibáñez Blanco 1956: 269). Así que la otredad marroquí es violenta, por ser marroquí, pero el "otro" marroquí además es violento con las mujeres en tanto que es hombre. 
patrilineal marroquí en la que hijos e hijas heredan nombre y religión a través de la línea del padre, no dejan de insistir en que sólo esta filiación paterna es la que asegura la herencia y proporciona prestigio y visibilidad. Por ello no hay "yuyues de júbilo, porque quien había nacido no era un varón " y aquello, sobre todo a los hombres, causa pena y decepción (Aramburu 1937: 47). Si hubiera sido un niño, por el contrario, "el yiu yiu repetido siete veces" (Bacaicoa 1955: 12) lo habría anunciado. Tener un hijo varón es lo más importante en estas ficciones, así lo expresa Bushra, afligida, porque ha tenido que mandar a las hijas de su primer matrimonio con los abuelos, no tanto por ser frutos de una relación anterior, sino porque eran mujeres.

- Estaba obsesionado por tener un muchacho, todos están obsesionados por tener hijos varones, como si en ello se les fuera el honor - dice resentida.

- ¿Y las niñas? - inquiere Hadush. (López Sarasúa 2002: 209)

Las niñas, durante los años siguientes al nacimiento sufren la violencia de una estructura patriarcal que menosprecia y desvaloriza la femenino, por lo que todas ellas comparten esa habitual "desgracia común" (Bacaicoa 1955: 88) a la que pocos personajes suelen oponer resistencia.

La violencia simbólica va calando en la autoestima de los personajes femeninos marroquíes, impregnando su socialización y llevándolas a aceptar su condición de inferioridad en los hechos más insignificantes. En las fiestas, hacen los preparativos mientras los hombres y parientes descansan (Bacaicoa 1955: 81). Luego, a pesar de que ellas lo han hecho todo, el honor recae en el anfitrión y a las mujeres no sólo no se las ve, sino que tampoco se las menciona ni por cortesía (Martín de la Escalera 1945: 126). Es más, para ellas poder comer algo tienen que esperar a que los hombres acaben y luego repartirse los restos que éstos han dejado (Martín de la Escalera 1945: 128). La práctica de la violencia simbólica va marcando el vivir de las mujeres que no pueden hablar con su marido los primeros días de matrimonio, ni levantar la vista de la punta de sus babuchas (Aramburu 1937: 101); tampoco pueden reírse en la calle con otro hombre, porque no guardarían las tradicionales formas de recato (Martín de la Escalera 1945: 137); ni sacarse una fotografía sin el permiso del esposo (Martín de la Escalera 1945: 73) e, incluso, deben esperar al beneplácito del marido celoso para visitar determinadas zonas de la ciudad (Bacaicoa 1955: 91).

Otra muestra usual en la narrativa estudiada de esta violencia simbólica hacia las mujeres es la implícita en la costumbre marroquí de cambiar la 
vestimenta de mujer soltera a casada. Encarna Cabello revela en La cazadora (1995) que, en realidad, era una manera de cuidar la reputación no sólo de ella sino también de los hombres a los que se la vincula. En esta novela, se describe a una joven marroquí con sus "abultadas carnes embutidas en un pantalón brillante de color rabioso que le marcaba rabiosamente caderas, muslos y piernas" (Cabello 1995: 98) y menos de un año después vistiendo "una chilaba incolora que le daba la forma de un baúl invertido a su cuerpo, y la cabeza religiosamente tapada con un pañuelo blanco por el que no aparecía ni un solo pelo" (Cabello 1995: 99). La narradora española de la novela se sorprende de este repentino cambio - de atrevido atuendo a chilaba austera- y lo califica poco más o menos que de inversión de identidad: "La misma cara de antes ahora transmutada en otra persona, cual si pasara una crisis de esquizofrenia: 'iQué loca es!"' (Cabello 1995: 99). Nos explica pronto que el cambio de indumentaria se debe a que la muchacha sería en breve ya la segunda esposa de un hombre mayor y, por ello, "como buena esposa, vestía a su gusto, obedecía sus órdenes” (Cabello 1995: 99).

\subsection{Violencia estructural}

La violencia estructural que sufre la "otra" marroquí no se recoge, como tal, en las ficciones analizadas aunque sí aparecen pinceladas de su situación de desventaja ante el ejercicio justo de sus derechos. Marruecos se describe como un escenario donde impera un orden social represivo que genera desigualdades de género ante las distintas instituciones pero esto es visto en todos los casos como algo natural e inherente a su sociedad. Así se dice que las mujeres deben abandonar los estudios para ayudar en las labores domésticas y cuidar de los hermanos menores (López Sarasúa 1988: 40); frente a la herencia, las mujeres obtienen menos legado en comparación con el hijo varón (Martín de la Escalera 1945: 135); si piden ellas el divorcio deben acceder a todo cuanto demanda el marido (Martín de la Escalera 1945: 158); si no se les ha concedido no se les permite siquiera salir de casa (Martín de la Escalera 1945: 170) e incluso se las puede detener y llevarlas a la cárcel, por el simple hecho de ser mujeres, si están en la calle a determinadas horas de la noche (Ibáñez Blanco 1956: 118). Por supuesto, muchas de estas situaciones las padecieron, también, las mujeres de la España franquista, justo, en el momento que buena parte del corpus analizado fue publicado. Sin embargo, las escritoras no suelen hacer analogías entre los semejantes contextos en los que vivían las mujeres de una y otra orilla: ambas sin vida política, confinadas en las fronteras del hogar y sujetos pasivos de una 
eterna minoría de edad. Su aproximación a la realidad marroquí que imaginaban hace suponer, de esta manera, que la situación de sumisión y discriminación por motivos de género era algo que sucedía, únicamente, en Marruecos ${ }^{5}$.

En consecuencia, la violencia estructural a la que es sometida la "otra" marroquí se va apuntando en estas novelas y relatos a través de pequeñas referencias y comentarios. No obstante, en lo tocante al tratamiento que recibe al contraer matrimonio, sí se subraya su mengua o perjuicio en comparación con los hombres marroquíes. La descripción de los matrimonios desde la fe islámica hace que salga a relucir el tópico de las bodas pactadas y, por consiguiente, la violencia que se considera inherente a las costumbres marroquíes: "Juzgo repulsivo el matrimonio de los moros. Las mujeres son tratadas y consideradas como bestias de más o menos precio... Se les niega el derecho de elección [...]" (Linares-Becerra 1962: 142).

Las descripciones de estos matrimonios acordados entre familias, descritos como verdaderos contratos de compra-venta en los que las mujeres son tratadas como bienes inmuebles, aparecen con frecuencia en las novelas y relatos analizados ${ }^{6}$. En muy rara ocasión aparece el fenómeno del amor romántico, tan mitificado en la cultura occidental o se relativiza diciendo que son cosas del pasado, como hace López Sarasúa: "Da gracias a que los tiempos cambian" (2002: 11). De hecho, se habla de "oferta de boda" (Ibáñez Blanco 1956: 12), donde sólo hay uniones que convienen a los intereses y ambiciones -"Primo rico dar muchas funas y tierras por mí" (Aranda 1945: 221)-, donde a la novia sólo le "falta que la envuelvan entre papeles de seda y la aten con un gran lazo" (Linares-Becerra 1971: 305) y el hombre, por su parte, espera impaciente para "gustar la mercancía que tan cara le ha costado" (Ibáñez Blanco 1956: 67). Veamos otro ejemplo más: “¿A esto se

5. Importante tener en cuenta que buena parte de los textos que constituyen la materia de análisis de este trabajo, fueron escritos y publicados bajo el recio control de la censura, ya sea la del Régimen de Primero de Rivera, la de la II República o la de la dictadura franquista, por lo que tampoco podían ser abiertamente críticos con lo que sucediera en España. Los escrutinios oficiales conllevaban una doble censura, la oficial y la (auto)impuesta por las propias autoras que no querían ver sus obras retenidas ni sancionadas. Fue éste un hecho relevante y a tener muy en cuenta hasta que se aprobó la Constitución Española en 1978. Toda la literatura española tenía que franquear los trámites burocráticos de la censura y más, incluso, en el caso de la narrativa popular como la que nos ocupa, en la medida que hay constancia de que uno de los criterios a la hora de revisar cualquier manifestación artística era el precio. La censura franquista, a sabiendas de que los libros caros eran muchísimo menos asequibles por el gran público, optó por controlar de forma más férrea las publicaciones baratas (Rioja Barrocal 2008: 93).

6. Un único caso he hallado en el corpus documental analizado de hombres forzados a contraer matrimonio. Se da en Noche nupcial sin novia (1956) donde la madre de la protagonista, Rejma, compra a "un marido que puede ser su hijo" (Ibáñez Blanco 1956: 179). 
reducían las recreaciones de las enclaustradas, de estas muchachas jóvenes que, sin transición, sin haber visto ni hablado a un hombre, son entregadas al que sus padres le eligen y cuyo rostro ignoran?" (Linares-Becerra 1971: 303).

Algunas de estas bodas forzadas son, de hecho, el motor de la trama, como en Noche nupcial sin novia (1956) cuyas primeras páginas describen la sensación de angustia de la joven protagonista. Redia afirma que se encuentra "saturada de amargura" y "consumida por la impotencia" (Ibáñez Blanco 1956: 9), llegando a compararse hasta con "un carnero al que van a degollar" (Ibáñez Blanco 1956: 264) o con "el plato fuerte del banquete" (Ibáñez Blanco 1956: 10). Las fuentes insisten en que las bodas son una transacción que no satisface a la interesada que habla del marido que le ha "tocado en matrimonio" (Cabello 2000: 13) y no al que ha podido escoger ella misma. Las ficciones subrayan, así, que la pareja de novios no solía conocerse antes de contraer matrimonio, o tan sólo se habían visto a través "del atisbo de una ventana" (Martín de la Escalera 1945: 90), es más, "existían mujeres ignorantes del rostro y nombre del esposo asignado hasta la misma noche de bodas" (López Sarasúa 1988: 35) por lo que, algunas de ellas, consideraban incluso el suicidio como forma de liberarse del sacrificio del matrimonio "porque ya estoy muerta aunque mi corazón siga latiendo" (Ibáñez Blanco 1956: 10).

Los personajes españoles que observan estas bodas por las calles, además, suelen vincularlas con la prueba de la virginidad de la novia, sobre la que también exponen su pensamiento, mostrando su más rotundo rechazo: "Mañana, puntualmente, la madre del novio recibirá la sábana nupcial que mostrará orgullosa a las mujeres, todo un trofeo" (López Sarasúa 2002: 153). Una virginidad que atañe a toda la familia, aunque como vemos en una de las últimas novelas publicadas, puede llegar también a escenificarse, como en el caso de aquellas mujeres que deciden coserse el himen: "Según me han dicho la operación es sencilla: se enhebra un hilo de seda, muy fino..." (López Sarasúa 2002: 246).

Otra violencia estructural relacionada con el matrimonio es la que tiene lugar cuando éste se acaba. En Alma de Marruecos (1938?) se relata cómo a Fátima, la lavandera rifeña, su marido la echó de casa para casarse con otra mujer más joven. A la violencia directa, visible y cultural que sufre Fátima al verse desprotegida en la calle por designios del que fuera su marido, se suma la violencia estructural de un sistema que respalda que éste se quede con los cinco o seis hijos que tienen en común. Y eso que Fátima tenía la condición de ciudadana libre y de pleno derecho. Los propios textos sostienen que son sus costumbres, marroquíes, y "hay que acatarlas" (Ibáñez Blanco 1956: 119). 
Un último caso, aún más flagrante, de violencia estructural y de ausencia total de derechos para la mujer, lo hallamos en el relato homónimo incluido en Zohora la negra y otros cuentos (1955). A Zohora también la echan de casa, con sus escasas pertenencias y sin poderse llevar tampoco a su hijo pequeño. De esta manera su marido podría contraer nuevas nupcias con otra esposa más adecuada a su nivel social. No es este un caso de divorcio, una ruptura del vínculo matrimonial por determinación judicial, sino más bien una imposición unilateral impuesta por el marido que recibe el nombre de repudio:

\begin{abstract}
Zohora, en la calle, en una calle cualquiera -todas le eran desconocidas-, miraba con los ojos ciegos la pared blanca que hería el sol con fuerza $[\ldots]$ ¿Y por qué? ¿Por qué?... [...] Ahora ella era una "viuda", una mujer sin hogar y sin nombre. [...] Se sentó en el suelo, deshecha. Los ojos ardientes seguían fijos en la blancura. $\mathrm{Y}$ así estuvo dos días y dos noches, sin dormir, sin comer, sin llorar, con los ojos abiertos y ciegos. (Bacaicoa 1955: 13)
\end{abstract}

Zohora se ve sola, en la calle, por lo que avisan a los parientes del que hasta entonces había sido su marido para trasladarla de zona, dado que anda por allí "como un bulto" (Bacaicoa 1955: 13). Unos hombres la conducen entonces hasta un coche de línea que se dirige a Nador, la suben a él engañada y allí, agotada, se duerme. Al despertar, descubrir la treta y ver que se aleja cada vez más de su hijo, pide al chofer que detenga el autobús. Éste, en vez de ayudarla, la acusa "de ser una despistada. Nunca saben a dónde van ni de dónde vienen" (Bacaicoa 1955: 14). La violencia estructural se conjuga entonces con la violencia de la propia comunidad -a la que la autora, además, describe manifiestamente española-, una violencia social y cotidiana que no ve agresión en hacerla bajar del autobús en una carretera cualquiera. Al preguntarle al conductor qué podría pasarle a la joven si no encuentra a nadie en su camino: "Pues que se... [...] Y la interjección se perdió en el ruido que hizo el motor al ponerse en marcha" (Bacaicoa 1955: 15).

La comunidad marroquí en estas ficciones es insensible al dolor ajeno y más si es una mujer quien lo sufre. No hay mejor muestra que lo que sucede a Rahma, la joven que muere pisoteada por un caballo. El niño que llevaba encima incluso pide ayuda, pero nadie hace nada para salvarla: "Todos, sordos y ciegos, siguieron andando con la cabeza hundida entre los hombros" (Bacaicoa 1955: 60).

Como se ha señalado, todos estos discursos explican la realidad de Marruecos como contraria a la dejada en España, en aquellas tierras africanas la sociedad en pleno maltrata a las mujeres. De la interpretación de las autoras se infiere que 
la mujer en la Península es valorada en igualdad de condiciones que el hombre y que dentro de las fronteras patrias estas cosas no suceden. Sin embargo, la narrativa posterior a los años 80 empieza a ser más autocrítica tanto con su propia realidad como con la observada, su realidad y la observada, por lo que denuncia que la violencia estructural no es patrimonio exclusivo de los marroquíes. Un testimonio de ello es la detención en España que sufre la narradora española de $L a$ cazadora (1995) por ir acompañando a su pareja sentimental y su cuñado, ambos marroquíes. Sólo por la nacionalidad de ellos son tomados los tres por delincuentes, se les vincula sin motivos a las drogas y se les habla de muy malas maneras: “¡Jeringuillas fuera! ¡Jeringuillas fuera! [...] A ver, papeles” (Cabello 1995: 44). Luego, cuando la española quiere acompañarlos a comisaría le espetan que no, que si ella quiere ir tendrá que hacerlo andando (Cabello 1995: 46), por lo que la muchacha echa a andar en una ya tardía noche de invierno por una solitaria calle.

\subsection{Violencia fisica}

La violencia más evidente, el maltrato físico del moro hacia la mora, tampoco escapa a estos textos, prolijos en diversos retratos de golpes y abusos que recalcan la subordinación femenina. Sobre todo, dentro el espacio doméstico, entorno dominante donde habita la "otra" marroquí, de ahí que lo normal sea que la violencia se cometa por parte de alguien con quien cohabite, normalmente, su marido.

En La llamada del almuédano (1990), Malika aparece con el rostro desfigurado por los hematomas, los arañazos y el llanto. Le ha pegado su marido con una correa, justo por el lado de la hebilla, el agresor confiesa que lo hizo porque "mujera diali dormir cama con otro hombre” (López Sarasúa 2000: 193). Pero no siempre hay explicación, sino que se considera la forma más habitual de tratar a las mujeres, la gente oye los gritos de una mujer desde el interior de su casa y comentan con naturalidad que deben de "estarla matando" (Ibáñez Blanco 1956: 257) pero siguen con sus quehaceres con tranquilidad. Sí, los textos muestran el maltrato hacia la mujer marroquí como algo normal y cotidiano. El moro sólo desea, en relación a su mujer, "aplastarla, pisotearla, maltratarla" (Martín de la Escalera 1945: 197), dado que a "las mujeres hay que tratarlas como a las mulas", porque "Dios no da las manos sólo para comer" (Ibáñez Blanco 1956: 257). Es más, algunos personajes locales verbalizan que hay "carne que luego de golpearla es más sabrosa" y que una "paliza a tiempo tiene más poder que muchos sermones” (Ibáñez Blanco 1956: 257). 
Otro ejemplo, lo encontramos en Alizmur (2000). Turía confiesa que sufre el mal humor de su marido en casa: "éste a veces tenía reacciones extrañas, violentas, que no parecían venir a cuento, pasando del buen humor a humillarla" (Cabello 2000: 29). Así, la mujer sufre "pequeñas tempestades de humillación" (AL: 29), en las que su marido "se enseñoreaba como tirano de su mujercita" (Cabello 2000: 30), a veces incluso delante de extraños: "Por favor, no me humilles delante de tu hermano, no quiero que me vea caer tan bajo; si estamos tú y yo solos lo puedo llevar mejor, pero delante de él, no, no..." (Cabello 2000: 29) y con unos golpes que, la dejaban "sin respiración (y puede que hasta sin sentido) por unos segundos" (Cabello 2000: 56).

En La cazadora (1995) somos testigos de otra agresión a una mujer marroquí, en este caso por parte de su propio primo. Éste, Muhasan, personaje central de la novela, acaba de enterarse que su padre ha convertido a su sobrina, muchísimos años más joven que él, en su amante. Supone esto para el joven la destrucción de la reputación de su madre, pero la violencia no sólo la descarga contra el padre "¿Tú un padre? Tú ya no eres mi padre desde ahora que te he encontrado con esa puta" (Cabello 1995: 9), sino también contra la joven que sale "despedida de la chabola y tras ella el hombre musculoso. [...] El hombre la alcanzó junto a una pileta de agua y le estampó un fuerte puñetazo en toda la boca gruesa" (Cabello 1995: 8-9).

Todos estos ejemplos sirven para que los personajes españoles que lo observan se sobrecojan de espanto y verbalicen "las más encontradas emociones, pero sobre todo, la de despecho contra una raza que trataba a las mujeres de la forma que acababa de ver" (Flavio 1938?: 103) o "¡Vaya situación la de las mujeres de aquí!" (Flavio 1938?: 102). En una de las novelas publicada por Marisa Villardefrancos, el médico protagonista descubre a una marroquí maltratada y confiesa que: "Le sobrecogió entonces ver la piel acardenalada y a trechos con un leve coágulo sobre una herida. Más señales de violencia se apreciaban en aquel cuerpo extenuado" (1953: 28). Fue entonces cuando preguntó: “¿Le pegaba Ibrahim?”, la respuesta fue lacónica pero certera, "mucho" (Villardefrancos 1953: 28). Tan sólo unas líneas más abajo asegura que la mujer era "apaleada y maltratada como una bestia" (1953: 28) y de hecho murió víctima de aquellas palizas.

La conclusión básica a la que llegan las autoras, desde su sensibilidad como europeas, es que la situación de las moras es miserable y que "ningún moro se conduce bien con su mujer" (Villardefrancos 1953: 157). Este discurso se explica por la legislación islámica, pero, también, por la relajación moral de 
la sociedad marroquí que, según las autoras, gusta de maltratar a sus mujeres. Dice uno de los protagonistas, árabe, de Y llegó el plenilunio (1944):

[...] no olvide que es sangre árabe la que corre por mis venas, y en nuestra raza esa conceptuación hemos logrado ocultarla solamente bajo la capa de esta nueva civilización. Pero, sin embargo, en cuanto hablamos un poco seguido de mujeres nos retrotraemos a la idea que siempre hemos tenido y las maltratamos psicológicamente, como yo acabo de hacerlo, sin respetar sus sentimientos. (Abellanosa 1944: 99)

En el contrapunto de los moros violentos que pegan a las moras, se sitúa al español respetuoso con las mujeres, tanto españolas como marroquíes. Se proyecta en estos libros el postulado de superioridad eurocéntrica y el hombre español se presenta como referente cultural o modelo a seguir. Lo hallamos en El sol nace de madrugada (1953), en la que el médico protagonista tiene una relación con Zahara. Ésta está sorprendida de que no la trate mal, de aquí que la "primera vez que tuvo un capricho y vio que su dueño no contestaba a sus exigencias con el dominio brutal del moro, quedó muy sorprendida y sufrió una leve decepción" (Villardefrancos 1953: 18). Para la marroquí aquello no era normal, se asegura que en ella faltaban "décadas de civilización para que pueda comprender el respeto que un hombre debe a una mujer" (Villardefrancos 1953: 20). Pese a ello, fue en ese momento cuando Zahara se dio cuenta de que con el español tenía total impunidad "hiciese lo que hiciese" (Villardefrancos 1953: 18-9), porque éste era un "hombre bueno" que "no le pegaba nunca y cumplía todos sus caprichos" (Villardefrancos 1953: 122). Después de todo, las mujeres marroquíes de estas ficciones tienen interiorizado que deben ser golpeadas por sus maridos, padres o hermanos y en ocasiones confiesan que han estado "a punto de cometer una ligereza, que, por mucha que sea la bondad de su dueño, habría resultado difícil que no le valiera el ser apaleada" (Aramburu 1937: 54); se acurrucan a un lado temblando como "un animalito que sabe que va a ser castigado sin piedad" (Nonell 1956: 128); se encogen "como una bestezuela acosada, esperando castigo, con los miembros sacudidos por fuerte temblor" (Ibáñez Blanco 1956: 236) o "se encogía en la colchoneta aguardando los golpes que presentía" (Ibáñez Blanco 1956: 255).

Como hemos visto, una de las estrategias representacionales más frecuentes es la auto-representación positiva a través de la comparación con Marruecos. Sin embargo, esta confrontación de realidades en muchas ocasiones devuelve más analogías que diferencias. En muchos textos se evidencia que golpear y maltratar 
a las mujeres no es sólo característico de un país de África como Marruecos sino un símbolo multicultural de dominación masculina que no entiende de fronteras. Dicho de otra manera, la violencia de género es un fenómeno estructural del patriarcado y, por tanto, se halla presente en el conjunto global de las sociedades patriarcales en las que, también, se ubica la europea.

A causa de ello podemos encontrar ejemplos en la narrativa analizada de hombres europeos que maltratan a mujeres, aunque, siendo estas ficciones de factura española, hay que admitir que son menos en cuantía. Un italiano que golpea a la marroquí con la que vive cuando bebe mucho en Zoco grande (1956) o un español en El sol nace de madrugada (1953) que aconseja a otro español sobre la mejor manera de tratar a las mujeres: "¿Quieres saber el secreto de volver dócil y respetuosa a Zahara? ¡Pégala!” (Villardefrancos 1953: 20). Otro ejemplo más en La llamada del almuédano (1990) donde María relata cómo un cliente de un bar quiso meterla a la fuerza en un coche: "Pasé toda la noche 1lorando; el tal señor me había destrozado el vestido; y era un español, ¿sabe? Un español de Tetuán, comerciante creo que era" (López Sarasúa 2000: 154). O, por poner un último ejemplo más, Rahama, la prostituta marroquí golpeada por el médico español en Tebib (1945). Éste primero "la mira como perdonándole la vida" (Aranda 1945: 64), luego "reacciona con violencia y, dándole un empujón, la arroja al suelo" (Aranda 1945: 65) y, entonces, le propina una brutal paliza, "sus manos se agarrotan brutalmente sobre los morenos brazos zarandeándola" y segundos después "el bofetón en plena mejilla suena como un trallazo" (Aranda 1945: 65).

\subsection{Violencia sexual}

La última de las violencias en la que me detendré es aquella que somete a la "otra" marroquí al abuso sexual. Una violencia naturalizada en la sociedad marroquí imaginada por las ficciones objeto de estudio, donde todos los matrimonios son pactados y las mujeres no deciden de modo voluntario acerca de su vida sexual o reproductiva. Sin embargo, me voy a detener únicamente en su perfil más extremo: la violación.

El sexo, desde sus orígenes, ha sido un arma de poder que somete y cosifica a las mujeres demostrándoles quién tiene el poder y delimitando de forma brutal el papel del dueño, el más fuerte, y del objeto, la más débil. El conjunto literario da testimonio de bastantes violaciones, la mayoría dentro del propio matrimonio y que la esposa acepta con sumisión: "esta noche cuando mi esposo tome posesión de mí" (Ibáñez Blanco 1956: 10). Sin embargo, me voy a detener en 
aquellas violaciones no consideras "lícitas", como podría llegar a entenderse la matrimonial, sino las llevadas a cabo por una persona distinta al cónyuge. En ese sentido, son cinco las violaciones halladas, en todas ellas tanto la víctima como el violador son marroquíes.

La primera de ellas, en orden cronológico, la hallamos en Pasión de moro (1925) y es especialmente brutal y virulenta porque expresa no sólo la degeneración de una persona, sino de todo un pueblo. Margarita Astray Reguera nos relata una violación colectiva de una mora por parte de unos hombres "poseídos de una alegría semisalvaje" y que "en turbulenta algarabía la rodearon, y ávidos de fuertes placeres, fueron estrechando uno a uno entre sus brazos el cuerpo moreno y lánguido de la pobre infeliz" (Astray Reguera 1925: 15).

La segunda de las violaciones, que conjuga tanto daño físico y sexual como moral, se recoge en Fatma. Cuentos de mujeres marroquies (1945). La violación en este caso de la "otra" marroquí es llevada a cabo por un vecino que aprovecha la oportunidad al saber que ella estaba sola en casa. Jadduya, la mora, intenta defenderse pero el hombre "la pisoteaba golpeándola al mismo tiempo con sus puños" (Martín de la Escalera 1945: 52). La violencia a la que es sometida Jadduya en este caso, no es sólo sexual o física, sino también institucional dado que cuando va al cadí a denunciar, se da cuenta de que su palabra no tiene validez. Le advierten que necesita testigos, si son de oídas, doce personas y, si lo han presenciado, dos hombres o cuatro mujeres. La razón de fondo es que dos mujeres valen por un hombre "a fin de que si una olvida la otra recuerde el hecho" (Martín de la Escalera 1945: 54).

Testigos, testigos, interrumpió Jadduya en el paroxismo del furor. Juro que cuanto digo es la verdad. Además, agregó bajando la voz, existe otro testigo de vista: mi criada que lo vio venir por el camino que pasa detrás de mi casa, andando muy deprisa con las babuchas en la mano.

- Pero no lo vio ni entrar ni salir, suspiró el Kadí. (Martín de la Escalera 1945: 53)

Jadduya está desesperada, no tienen en cuenta ni sus cardenales, ni sus arañazos, ni su palabra. El cadí decide entonces que deben jurar sobre El Corán, cree que nadie se atreve a hacerlo en falso, pero otra vez el agresor afirma no haber estado jamás en la casa de Jadduya. El relato termina con la inexplicable ceguera del violador, la moraleja es evidente: no hay justicia de los hombres, pero sí justicia divina. 
La siguiente violación es la de Zohora en el relato principal de Dora Bacaicoa, Zohora la negra y otros relatos (1955), aunque ella -aquejada de mil desgracias más- la acepta sin resistencia: "Un hombre subía. Al advertir su paso inseguro, sonrió. Se acercó a ella y de un manotazo la puso en la oscuridad y le arrancó el pañuelo. Sus labios hambrientos besaron los de Zohora" (Bacaicoa 1955: 19). Llama especialmente la atención que, tras consumar la violación, el agresor paga a Zohora y convierte, de esta manera, la violación en prostitución. Intenta así desplazar el daño causado y ocultarlo en los pliegues del intercambio sexual por motivo económicos.

Concha López Sarasúa recoge las dos últimas violaciones. La primera de ellas en A vuelo de pájaro sobre Marruecos (1988), la víctima es la mora Lasmía. Esta joven, perteneciente a una generación menos dispuesta a acatar un destino como mujer objeto, cuestiona su vida mientras observa la ropa nupcial que yace en ese momento sobre la cama. En breve se va a casar, sin embargo, en su caso no es víctima de un enlace en el que hayan intervenido conciertos familiares o intereses, se casa por amor. De ahí que la protagonista verbalice que "las mujeres de su país comenzaban a emanciparse; era un buen augurio" (López Sarasúa 1988: 42). No obstante, a pesar de que Lasmía considera que se están obrando cambios, también ella ha sufrido violencia por haber nacido mujer. La primera vez, en la más tierna infancia, cuando su padre intentó violarla:

Estaba dormida junto a su hermana Hadush cuando advirtió el calor de un cuerpo pegado al suyo, una respiración entrecortada y húmeda cerca del oído, casi acariciante y, entremezcladas e incoherentes palabras incitándola al abandono y al placer. La mano de su padre la aprisionaba con fuerza mientras pugnaba por introducir, entre sus temblorosos muslos, un miembro cuyas dimensiones nunca habría imaginado su joven mente. (López Sarasúa 1988: 41)

La última violación, también recogida en un texto de Concha López Sarasúa, se relata en La llamada del almuédano (1990). A Halima la violan en el hammam con tal violencia que la dejaron inconsciente en el suelo y "cuando despertó estaba sola" (2000: 197). No se atrevió a contárselo a nadie distinto a su madre, porque, además, por esa violación quedó embarazada. Halima intentó explicar el embarazo diciendo que había sido por sentarse en un baño público pero su padre, iracundo, la echó de casa.

En todos los casos expuestos, los violadores eran hombres marroquíes y con esto las autoras consiguen ejemplificar que estamos ante una sociedad tan degradada que a las mujeres hay que salvarlas de sus propios hombres. Un tópico que 
Gayatri Spivak fundamentó en la expresión "hombres blancos que salvan a las mujeres morenas de hombres morenos" (2010: 282) y, de ahí, que se ponga sobre la mesa de las necesidades la urgente protección de las mujeres marroquíes por parte del progreso occidental.

\section{Conclusiones}

Señaló Ángeles de la Concha que con la perspectiva que da el tiempo transcurrido, la literatura occidental ha ejercido todo tipo de violencia sobre los personajes femeninos, sobre todo en lo referente a la forzosa domesticidad que las ha hecho llegar a considerar como salida la locura o la muerte (2010: 144). Sin embargo, la narrativa occidental en general, también la actual y, por supuesto, no toda, está plagada de mujeres que sufren maltratos, palizas o violaciones por razón de género y, en ningún caso suele considerarse que sean hechos derivados de la cultura patriarcal en la que surgen como sucediera con la narrativa española de tema marroquí sino hechos puntuales aislados derivados de parejas destructivas, pervertidos sexuales, etc.

La narrativa española de tema marroquí analizada, influida por el orientalismo más político y sus intereses imperialistas ha insistido en que los y las marroquíes son violentos, primero porque su violencia ayudaba a justificar los propios ataques, maniobras y acciones bajo el eufemismo de la defensa nacional durante la mayor parte del siglo XX. Y, en segundo lugar, porque además de legitimar el discurso intervencionista o hegemónico en épocas posteriores, también subrayaba el atraso marroquí y aquello ponderaba la superioridad europea. Además, nos hallamos ante unas ficciones de aventuras a tierras exóticas y la violencia era un componente fundamental de todas ellas que hacía más atractiva la lectura del género. En este sentido, las aproximaciones de las autoras son bastante utilitarias y pragmáticas y, en ningún caso, buscaban sacudir conciencias. La narrativa analizada en este trabajo, fiel a estos juicios de valor, ha contribuido de modo persistente a consolidar la imagen de los y las marroquíes como violentos, crueles, perversos y traicioneros por lo que la violencia debe entenderse, desde estas ficciones, como un tópico literario.

Finalmente, tras el análisis de esta narrativa de tema marroquí escrita por mujeres se ha podido constatar que éstas, por el hecho de serlo, no son deudatarias de una mayor sensibilidad ante el abuso. Estas autoras, coartadas por los patrones culturales de su lugar de origen, se han visto a sí mismas superiores étno-racialmente por lo que sus discursos orientalistas casan homogéneamente con los emitidos por los autores varones que, igualmente, publicaron narrativa de tema marroquí durante el pasado siglo XX. 


\section{Bibliografía}

ABELlANOSA, J. M. (1944). Y llegó el plenilunio. Madrid: Gráficas Reunidas. ARAMBURU, R. de (1937). Ojos largos. Madrid: Editorial Española.

ARANDA, R. M. (1945). Tebib. Zaragoza: Artes Gráficas.

ASTRAY REGUERA, M. (1925). "Pasión de moro". Los contemporáneos 879, Madrid.

ATWOOD, M. (2013). La maldición de Eva. Barcelona: Lumen.

BACAICOA, D. (1955). Zohora la negra y otros cuentos. Tetuán: Colección Manantial.

BURGOS, C. de (1989). "En la guerra" en La flor de la playa y otras novelas cortas. (Ed. C. Núñez Rey). Madrid: Castalia: 163-218.

CABELLO, E. (1995). La cazadora. Melilla: Textos Mediterráneos.

CABELLO, E. (2000). Alizmur. Barcelona: Meteora.

CARRASCO GONZÁLEZ, A. M. (2000). La novela colonial hispanoafricana. Las colonias africanas de España a través de la historia de la novela. Madrid: Casa de África.

CHARLES, M. (1993). Etxezarra. Barcelona: Anagrama.

DE LA CONCHA, Á. (2010). "En el umbral de una nueva poética: cambios en la representación literaria de la violencia de género" en El sustrato cultural de la violencia de género. (Coord. Á. de la Concha). Madrid: Editorial Síntesis: $143-172$.

DURANGO, M. A. (1943). Ojos verdes. Madrid: Editorial Pueyo.

ESTEVEZ DE CASTRO, M. P. (1954). El convoy de la muerte. Madrid: Pueyo. FERNÁNDEZ CUBAS, C. (2009). El vendedor de sombras. Barcelona: Alfabia.

FLAVIO, R. (1938?). Alma de Marruecos. Barcelona, Sevilla: Betis.

IBAÑEZ BLANCO, B. (1956). Noche nupcial sin novia. Granada: B.I.B. Imprenta José María Ventura Hita.

JADRAQUE, M. T. (1954). Halima. Madrid-Cádiz: Escélicer.

LINARES-BECERRA, C. (1962). Cita en el paraíso. Madrid: C.L.B. Imprenta Sáez.

LINARES-BECERRA, C. (1971). Muchachas sin besos. Madrid: Cunillera.

LITVAK, L. (1985). El jardín de Aláh. Temas del exotismo musulmán en España (1880-1913). Granada: Don Quijote.

LÓPEZ BARRANCO, J. J. (2006). El Rif en armas. La narrativa española sobre la guerra de Marruecos (1859-2005). Madrid: Marenostrum. 
LÓPEZ GARCÍA, D. (1994). El Blocao y el Oriente. Una introducción al estudio de la narrativa del siglo XX de tema marroqui. Murcia: Universidad de Murcia.

LÓPEZ SARASÚA, C. (1988). A vuelo de pájaro sobre Marruecos. Alicante: Cálamo.

LÓPEZ SARASÚA, C. (2000). La llamada del almuédano. Alicante: Cálamo.

LÓPEZ SARASÚA, C. (2002). ¿Qué buscabais en Marrakech? Alicante: Cálamo.

MARSHAL, B. K. (1992). Teaching the Postmodern. Fiction and Theory. New York, London: Routledge.

MARTEL, C. (1956). ;Demasiado tarde! Madrid: Pueyo.

MARTÍN DE LA ESCALERA, C. (1945). Fatma. Cuentos de mujeres marroquies. Madrid: Publicaciones África. Instituto de Estudios Políticos.

MARTÍNEZ MONTÁVEZ, P. (1976-7). "La repercusión de los problemas del mundo árabe contemporáneo en el intelectual español (1939-1974)”. Almenara, Revista sobre el mundo árabo-islámico 10: 3-47.

MOI, T. (1988). Teoría literaria feminista. Madrid: Cátedra.

NONELL, C. (1956). Zoco grande. Madrid: Colenda.

SPIVAK, G. CH. (2010). Crítica de la razón poscolonial. Hacia una historia del presente evanescente. Madrid: Akal.

RIOJA BARROCAL, M. (2008). Traducción inglés-español y censura de textos narrativos en la España de Franco: TRACEni (1962-1969). Tesis doctoral, Universidad de León.

RIVAS, J. M. (1949). Noches de Tánger. Barcelona: Bruguera.

VILLARDEFRANCOS, M. (1953). El sol nace de madrugada. Madrid: Biblioteca de Chicas.

VIÑUELAS, M. (1946). Los vencidos. Madrid: Aguilar. 